\title{
Investigation on Microbial Fuel Cells Fabricated from Recyclable Materials for Energy Generation and Wastewater Treatment
}

\author{
Somil Thakur and Bhaskar Das $\dagger$
}

Department of Environmental and Water Resources Engineering, School of Civil Engineering, VIT, Vellore, Tamil Nadu 632014, India

†Corresponding author: Bhaskar Das; bhaskar.ju@gmail.com

Nat. Env. \& Poll. Tech.

Website: www.neptjournal.com

Received: 12-01-2021

Revised: 26-02-2021

Accepted: 16-03-2021

\section{Key Words:}

Bio-electricity

Renewable energy

Sustainability

Wastewater treatment

\section{ABSTRACT}

Microbial fuel cells (MFC) have gained focus due to their diversity in operating conditions \& substrates for the generation of sustainable green energy. In the present study, novel MFC has been fabricated using the recyclable aluminum can as air-cathode and graphite rod as anode for the treatment of domestic wastewater and simultaneous power generation. Three different substrate (COD) concentrations, high (>800 mg. $\left.\mathrm{L}^{-1}\right)$, medium (250 mg. $\left.\mathrm{L}^{-1}-800 \mathrm{mg} \cdot \mathrm{L}^{-1}\right)$ and low $\left(<250 \mathrm{mg} \cdot \mathrm{L}^{-1}\right)$ were used. The maximum COD removal efficiencies, voltage generation, power densities were found to be $80 \%, 0.71 \mathrm{~V}$, and $304.46 \mathrm{~mW} \cdot \mathrm{m}^{-2}$ respectively in high strength wastewater setup. In both medium and low strength wastewater setups, after 288 hours, the COD was reduced below $50 \mathrm{mg} \cdot \mathrm{L}^{-1}$ thus limiting the electricity generation substantially. Setup with low-strength wastewater produced a maximum CE (\%) of 13.80. Overall results showed that although high-strength wastewater produced better and maximum power densities, medium and low-strength wastewater setups were more consistent in energy generation throughout the experiment.

\section{INTRODUCTION}

Rapid urbanization and intense industrialization have increased the consumption of energy sources substantially in recent decades (Zou et al. 2016). The present energy requirement is majorly dependent upon the non-renewable sources mostly fossil fuels, which sums of around $80 \%$ of the global energy supply (Gielen et al. 2019). Although these sources are considered to be available in abundance, they are depleting quickly like never before due to excessive resource utilization. Moreover, the conversion of fossil fuels into energy poses numerous adverse effects on the environment, leading to the emission of carbon dioxide, SOx and NOx gases which are harmful to the environment (César et al. 2015). Taking this into account, researchers have been working on alternative energy sources in the form of renewable energy, e.g., solar energy, wind energy, geothermal, energy from biomass, etc. Among these, Microbial Fuel Cell (MFC) technology has also emerged as an environment-friendly solution that takes on the concept of energy from biomass, thus providing wastewater treatment and energy generation from it simultaneously without requiring any external power source with additional benefits of minimal to no emission of greenhouse gases (Chen \& Smith 2018). MFC's use anaerobic microorganisms to decompose the organic matter in the anodic compartment and breaking it down into $\mathrm{CO}_{2}$, hydrogen ions, and electrons. The electrons are transported on anode through soluble shuttle or direct transfer with the help of exo-electrogenic bacteria and are transferred through the external circuit to the cathode (Choudhury et al. 2017, He et al. 2017). The hydrogen ions (protons) are transferred from anode to cathode chamber through fluidized media and meet with the electrons in the cathode compartment thus completing the circuit. Depending upon the reactor design and electrode configurations MFC's can be of various types, e.g., Single chamber MFC, Double chamber MFC, air cathode MFC, benthic MFCs, stacked MFC and MFC integrated with various treatment methodologies (He et al. 2017, Ezziat et al. 2019). Double chamber MFC's have two compartments, one typically referred to as an anode chamber and one as a cathode chamber which are joined by some cation mediator (e.g., Nafion membrane, salt bridge, etc.). However, the required redox potential for MFC can also be maintained in single-chambered systems (Logan et al. 2006). Anoxic anode zone and aerobic cathode zone maintained in a single compartment can create a redox gradient facilitate the transfer of electrons from anode to cathode (Seeber et al. 2015).

The substrate is considered the most important biological factor in MFC which can be pure or complex in nature (Wu et al. 2020). Among the different substrates, municipal wastewater is the most studied due to its 
diverse microbial community, significance, and inherent energy potential. It has been found that municipal wastewater contains approximately ten times the energy in the form of biomass that will be required to treat it (Maktabifard et al. 2018).

The available studies on MFC systems indicate limiting factors such as internal resistance and the capital cost for the installation especially for the electrode materials (Feng et al. 2014, Ge \& He 2016). Anode material directly influences microbial growth, electron transfer, should have biocompatibility, low resistance, and a large surface area for the microorganism to sustain. For fulfilling that, carbonaceous materials like carbon cloth, graphite plate/rod, and carbon brush are commonly used as anode material (Luo \& He 2016). The cathode influences the power generation due to lower Oxygen Reduction Potential (ORR) than the organic anaerobic oxidation in the anode (Kannan \& Kumar 2016). To overcome this ORR barrier, the design of the cathode mainly focuses on catalysts or artificial electron mediators to promote higher ORR in the cathode. Some of the abiotic cathodes commonly used are platinum $(\mathrm{Pt})$, transition metal oxides activated carbonaceous material electroconductive polymers, and metal macrocyclic compounds (Zuo et al. 2007, Narayanan \& Thakur 2010). The electrodes are one of the major components of MFC based on performance and economic consideration (Choudhury et al. 2017). Though there are possibilities to reduce the cost of electrode material without compromising the performance, there is inadequate information regarding low cost, indigenous, reusable/recyclable electrode material as most of the studies on MFC focus on optimization of design parameters and operating conditions. Wang et al. (2011) used recycled coated tire crumbs in the anode and air cathode and found PD and CE of $421 \mathrm{mWm}^{-2}$ and $25.1 \%$ respectively for a single chamber MFC of $140 \mathrm{~mL}$ volume. The 2-4 layers of graphite coating in the tire crumbs achieved the specific surface area 10 times more than same-size graphite granules whereas the cost of the electrode is almost 1000 times less. Lefebvre et al. (2012) fabricated a two-chamber MFC with Inconel 718, a recycled scrap material, as cathode with carbon cloth for synthetic wastewater as substrate and achieved maximum acetate removal of $99.7 \%, \mathrm{PD}$ of $36 \mathrm{Wm}^{-3}$. Using the recycled material, they reduced the cost of the electrode from $50 \%$ to $26 \%$ without reduction of performance and leaching of metal even after one year of operation. Low cost commercially available carbon fiber (CF) coated with nickel (Ni), used as cathode material (Luo \& He 2016) showed Ni-CF have better performance in respect to electricity generation and cost-effectiveness when compared with carbon cloth CC, which is a conventional electrode material for the cathode. Another recent work (Thakur \& Das 2020) used fabricated composite anode made of Luffa aegyptiaca (natural scrubber) and graphite plate for the treatment of municipal wastewater and $\mathrm{RO}$ concentrate mix and achieved maximum removal of $95.83 \%, 87.61 \%$, and $94.06 \%$ of COD, TDS, and TSS respectively with a maximum voltage of $0.530 \mathrm{mV}$ and NER of $19.51 \mathrm{Whkg}^{-1} \mathrm{COD}^{-1}$. The integration of low cost highly porous and locally available material increased the COD, TSS, and TDS removal efficiency and achieved more NER when compared with the MFC system without a natural scrubber.

The aluminum beverage can represent about $80 \%$ of total aluminum waste globally which contains $97 \%$ metal aluminum. Around 475 billion cans are produced each year, with differing percentages of them being recycled in different nations (Yoo et al. 2007). According to a report by the United States Environmental Protection Agency (US EPA 2015), the recycling rate of aluminum used in packaging and beverage industries is just $32.8 \%$ while in India it stands at $25 \%$. It is clear that this metal has some return value but is not being recycled up to the extent. Apart from the recycling, the waste aluminum cans have served as a useful metal in several studies which investigated other value-added applications like the synthesis of zeolite nanostructure (Abdelrahman 2018), hydroxysodalite nanoparticles (Abdelrahman \& Hegazey 2019), hydrogen generation through PEM (Martínez et al. 2007), synthesis of $\gamma-\mathrm{Al}_{2} \mathrm{O}_{3}$ (Abdelkader et al. 2018), etc. In a previous study, aluminum was used as an electrode material, and the more conductive nature of aluminum alloy mesh was found to lower internal resistance (Chen et al. 2013). The electrical performance of aluminum alloy mesh carbon cloth electrodes is enhanced in comparison with conventional carbon cloth electrodes. In the present study, recyclable aluminum cans have been used as air cathode in MFCs with graphite rod as anode and different strengths (high, medium, and low) of domestic wastewater as substrate. An unconventional approach was adopted in this study to fabricate the setup by not providing any PEM and letting the ions flow with the help of surface transfer. In most high-voltage domestic electrical applications, short circuits would cause circuit damage, but because energy generation in normal MFCs is substantially lower, this preliminary investigation was designed to see how much energy might be generated without utilising PEM while using recyclable materials. All the available studies with high strength wastewater correspond either to industrial (tannery (Palanisamy et al. 2020), dairy (Mansoorian et al. 2016), pharmaceutical (Velvizhi \& Venkata Mohan 2011)) or synthetic wastewater. Hence, high strength domestic sewage wastewater has been considered as substrate in MFCs. Further the results were compared with other studies on MFC using domestic wastewater as substrate. 


\section{MATERIAL AND METHODS}

\section{Fabrication}

Cylindrical aluminum cans made up of 3004-H19 alloy with characteristics (Matweb 2020) as mentioned in Table 1 (diameter - $66 \mathrm{~mm} \&$ height - $115 \mathrm{~mm}$ ), generally used as beverage cans, were used as the containment as well as cathode while graphite rods of $10 \mathrm{~mm}$ diameter, $50 \mathrm{~mm}$ height (48 mm effective) were used as an anode. Each of them was cleansed with $0.5 \mathrm{M}$ aqueous HCL solution and rinsed ultrasonically with double distilled water. Anode chambers were sealed and made airtight with the help of thermocol and edges were sealed with epoxy to maintain an anaerobic environment, while cathode chambers were kept open to the atmosphere for an anaerobic environment. Copper wires were used to connect anode and cathode via an external open circuit connected with a multimeter (Fig. 1).

\section{Wastewater Collection}

Wastewater was collected from two different treatment plants of VIT Vellore. Raw wastewater (R1, R2) was collected from the inlet chamber of the wastewater treatment plants; primary treated wastewater $(\mathrm{S} 1, \mathrm{~S} 2)$ was collected from the outlet of the settling chambers; secondary treated wastewater (T1, T2) was collected from the secondary clarifier outlets of the activated sludge system. As per the COD concentration, they were classified as high strength, medium strength \& low strength wastewater respectively. The influent COD concentrations are mentioned in Table 2.

\section{Operation}

A total of six systems were fabricated with an anode volume of $165 \mathrm{~mL}$ each and operated at room temperature $\left(25-30^{\circ} \mathrm{C}\right)$. Influent wastewater was classified with different COD range [39] (i.e.- High wastewater strength (R1, R2 > $800 \mathrm{mg} . \mathrm{L}^{-1}$ ), Medium strength $(250<\mathrm{S} 1, \mathrm{~S} 2<800)$ \& Low strength $(0$ $<\mathrm{T} 1, \mathrm{~T} 2<250$ ). COD was analyzed using COD digester [Spectroquant TR320] (APHA 2017), voltage (open circuit) with multimeter [MAS830L], $\mathrm{pH}$ with digital $\mathrm{pH}$ meter [Hanna HI98107]. COD represents the degree of organic pollution in water bodies ( $\mathrm{Li}$ et al. 2018) which is being consumed by microbes for the generation of energy in MFCs. $\mathrm{pH}$ also plays a vital role in wastewater treatment (Yaseen \& Scholz 2019) as variation in $\mathrm{pH}$ can affect the functioning of microbial activity. Electrogenic microbial culture (geobacter, shewanella, etc.) is neutrophilic and can only sustain in a $\mathrm{pH}$ range of 6-8. Normalized energy recovery (NERs) is considered as an important parameter for comparison between different MFCs because of its non-dependence on the size of the reactor while considering wastewater flow rate and organic removal efficiency for its calculation (Das et al. 2019). COD removal, NERs, Power, PD \& CE were calculated by using Equation (1), (2), (3), (4) \& (5) respectively:

$$
\begin{aligned}
& \text { COD Removal Efficiency }=\frac{\mathrm{C}_{\mathrm{i}}-\mathrm{C}_{\mathrm{e}}}{\mathrm{C}_{\mathrm{i}}} \times 100 \\
& \text { Power }(\mathrm{P})=\text { Current }(\mathrm{I}) \times \text { Voltage }(\mathrm{V}) \\
& \text { Power Density }(\mathrm{PD})=\frac{\text { Power }}{\text { Area of anode }}
\end{aligned}
$$

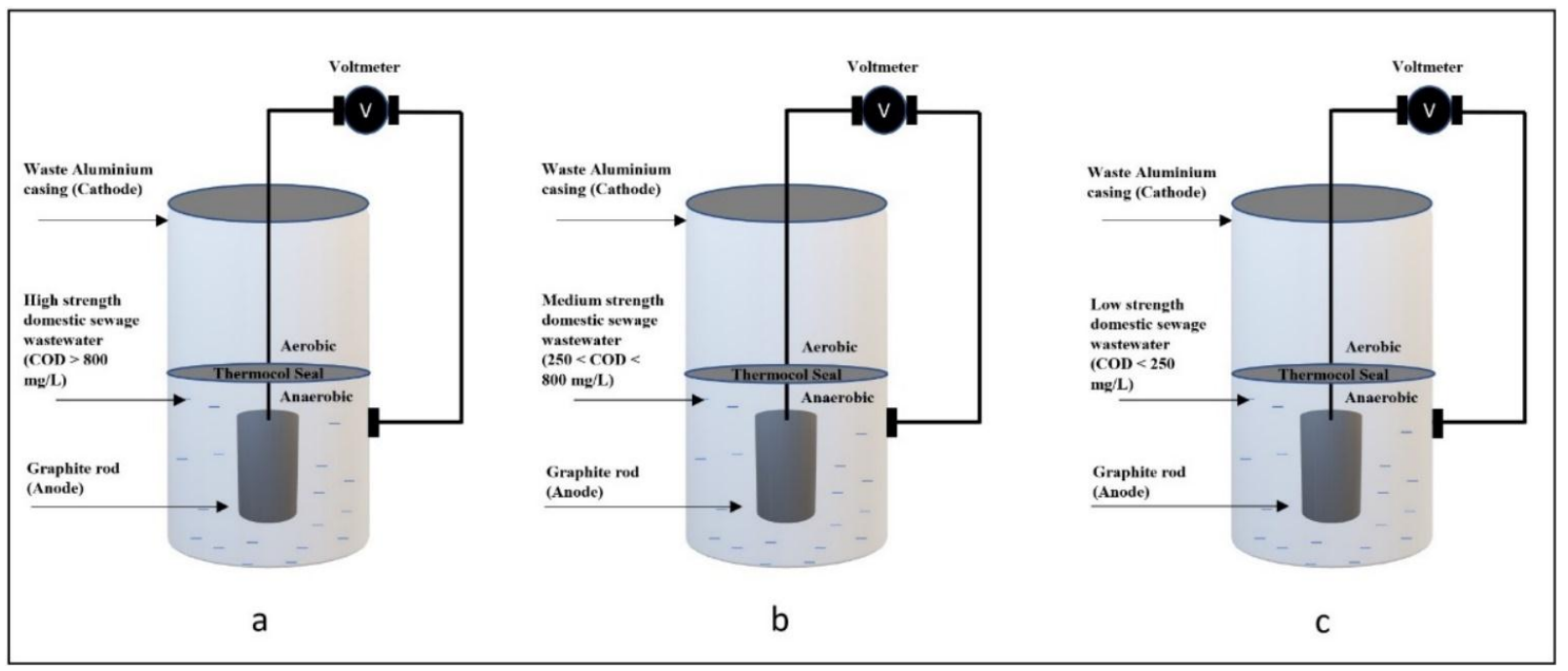

Fig. 1: Schematic diagram of experimental systems representing; (a) - System with high strength wastewater (R1, R2), (b) - System with medium strength wastewater (S1, S2), (c) - System with low strength wastewater (T1, T2). 
Normalized Energy Recovery (NERs) $=\frac{\mathrm{P} * \mathrm{t}}{\Delta \mathrm{COD}} \ldots$

$$
\text { Coloumbic Efficiency (CE) }=\frac{\mathrm{M} \int_{0}^{\mathrm{t}} \mathrm{Idt}}{\mathrm{Fbv}_{\mathrm{a}} \Delta \mathrm{COD}}
$$

where, $\mathrm{C}_{\mathrm{i}}=$ Initial COD $\left(\mathrm{mg} . \mathrm{L}^{-1}\right), \mathrm{C}_{\mathrm{e}}=$ Final COD $\left(\mathrm{mg} . \mathrm{L}^{-1}\right)$, $\mathrm{DCOD}=\mathrm{C}_{\mathrm{i}}-\mathrm{C}_{\mathrm{e}} \cdot \mathrm{P}=$ Power, $\mathrm{t}=$ time(hours), $\mathrm{DCOD}=$ Removed COD, $\mathrm{M}=$ Molecular weight of oxygen (32), $\mathrm{V}$ = Voltage, $\mathrm{I}=$ Current, $\mathrm{F}=$ Faraday's constant (96485), $\mathrm{b}=$ 4 (number of electrons exchanged per mole of oxygen), $v_{a}$ $=$ Volume of Anode.

\section{RESULTS AND DISCUSSION}

\section{COD Removal and pH}

COD removal has been calculated with the help of Equation (1). All systems showed gradual COD removal during the experiment in similar trends (Fig. 2). R1 and R2, which had the highest COD loading showed cumulative removal of $83.33 \%$ \& $91.66 \%$. A gradual reduction in COD was because of slowly increasing microbial activity in the anode zone of systems which led to anaerobic degradation of organic matter. COD removal efficiencies were calculated after every 72 hours and its variation has been mentioned in Fig. 2(d), while cumulative values have been mentioned in Table 2. Anaerobic microbial culture degraded the organic matter and converted it into electrons and hydrogen ions. The trends of COD reduction in all systems were almost similar. However, more COD removals were achieved by R1, $\mathrm{R} 2$ because of the presence of more available biomass but it did not work synergistically with energy generation which has been discussed later. It was also found that the stability of systems with low organic loading was better. The COD removal efficiencies of the present study, when compared with available literature considering domestic wastewater as substrate, were similar at different substrate concentrations (Tatinclaux et al. 2018, Zhang et al. 2015, Ahn et al. 2014) as presented in Table 2 .

The $\mathrm{pH}$ of influent wastewater was in the range of 7.0-9.0. $\mathrm{pH}$ decreased gradually with time in all systems. However, the $\mathrm{pH}$ of systems with high-strength wastewater

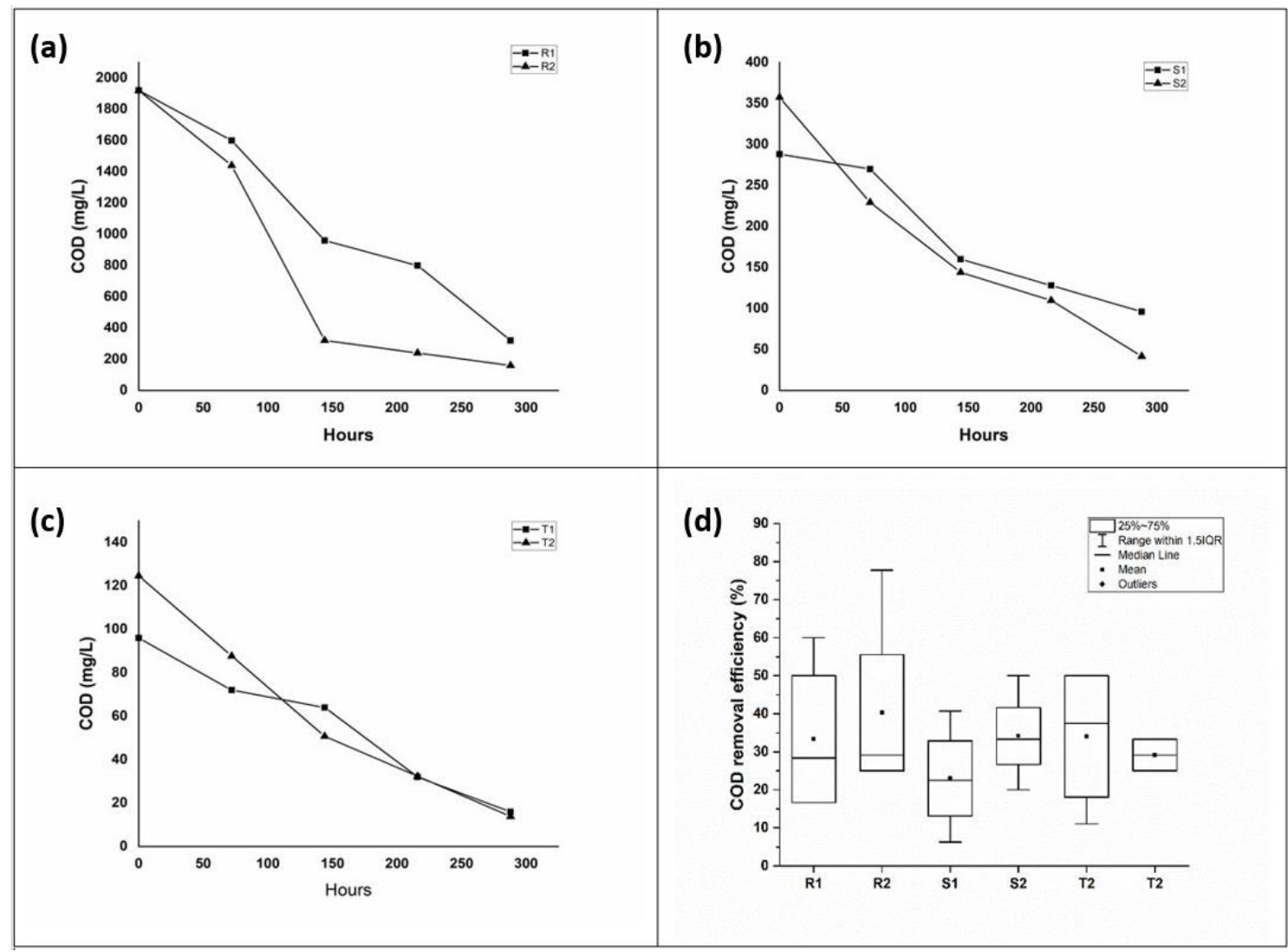

Fig. 2: The reduction in COD (mg.L ${ }^{-1}$ ) with respect to time. (a) - High strength wastewater (R1, R2), (b) - Medium strength wastewater (S1, S2), (c) Low strength wastewater (T1, T2), (d) - Box plot showing the variability of COD removal efficiencies in all systems. 
Table 1: Characterization of the Aluminum casing (Matweb 2020).

\begin{tabular}{|llll|}
\hline \multicolumn{2}{c|}{ Alloy 3004- H19 } \\
\hline Mechanical properties & & Element properties \\
\hline Hardness, Brinell & 79 & Aluminum, Al & $95.5-98.2 \%$ \\
Tensile Strength, Ultimate & $295 \mathrm{MPa}$ & Copper, Cu & $<=0.25 \%$ \\
Tensile Strength, Yield & $285 \mathrm{MPa}$ & Iron, Fe & $<=0.70 \%$ \\
Elongation at Break & $2 \%$ @ Thickness $1.60 \mathrm{~mm}$ & Magnesium, $\mathrm{Mg}$ & $0.80-1.3 \%$ \\
& & Manganese, $\mathrm{Mn}$ & $1.0-1.5 \%$ \\
Modulus of Elasticity & $69.0 \mathrm{GPa}$ & Other, each & $<=0.05 \%$ \\
Poissons Ratio & 0.35 & Other, total & $<=0.15 \%$ \\
Shear Modulus & $25.0 \mathrm{GPa}$ & Silicon, Si & $<=0.30 \%$ \\
Shear Strength & $180 \mathrm{MPa}$ & Zinc, Zn & $<=0.25 \%$
\end{tabular}

was lowest. It can be linked to COD removal and voltage generation, since abundant biomass undergoing anaerobic reactions in $\mathrm{R} 1$ and $\mathrm{R} 2$ may have resulted in the formation of higher amounts of acids and acetate, lowering the $\mathrm{pH}$ to 6.9 in $\mathrm{R} 1$ by the end of the experiment. However, due to the higher initial $\mathrm{pH}$ of $\mathrm{R} 1, \mathrm{R} 2$, very little energy generation was detected. Throughout the trial, the $\mathrm{pH}$ of the medium and low strength wastewater systems was in the range of 7 to 9 .

\section{Voltage Generation}

$\mathrm{R} 1$ and R2 produced maximum voltages of 0.67 and $0.71 \mathrm{~V}$ respectively. This can be related directly to the COD removal by the systems (Fig. 2), as maximum COD removals by R1 and R2 were between 72-144 hours when the voltage generations were also maximized. However, R1 and R2 showed slower electrochemical activity initially because of high organic loading and lower $\mathrm{pH}$, but once the electrochemical culture was achieved, this high organic loading helped them to reach the highest voltage peaks in the end. Also, variation of voltage in R1 and R2 is significant as compared to other systems which shows the inconsistency of performance in the case of high strength substrates. In the case of S1, S2, $\mathrm{T} 1$ and $\mathrm{T} 2$, voltage generations were quite efficient from the initiation of the experiment and they produced peak voltages of $0.61,0.66,0.36$, and $0.41 \mathrm{~V}$ respectively. Electrochemical activities started earlier in these systems due to lower organic loading, thus leading to higher voltage generations, but due to less substrate available, after reaching the peak, it started to decline by the end of the experiment (Fig. 3). The voltage generation of similar studies considering domestic wastewater as a substrate has been included in Table 2 . The maximum voltage generated from the present study is comparable with previous results (Ahn \& Logan 2013) in all substrate concentrations.

\section{Power Density and Normalized Energy Recovery}

Power Density (PD) signifies power generated by a system with respect to the surface area of the electrode $\left(\mathrm{mW} \cdot \mathrm{m}^{-2}\right)$. Maximum PDs obtained by different systems have been mentioned in Table 2. Although maximum PDs were obtained by R1 and R2, the lower average values show that their power generation consistencies were low. Medium strength wastewater managed to produce approximately similar maximum PDs with much better average values and consistency. These consistencies were also verified by Normalized Energy Recovery (NERs) [Fig. 4]. Systems with high-strength wastewater produced maximum NERs of $0.22 \mathrm{kWh} / \mathrm{kgCOD}$ during $216-288$ hours, medium-strength wastewater produced $0.79 \mathrm{kWh} / \mathrm{kgCOD}$ during 144-216 hours, and low strength wastewater produced NERs of 0.65 $\mathrm{kWh} / \mathrm{kgCOD}$ during 72-144 hours. In the case of low strength wastewater systems, there is an increasing trend of NERs till 144 hours, after which it started decreasing from $0.65 \mathrm{kWh} /$ $\mathrm{kgCOD}$ to $0.15 \mathrm{kWh} / \mathrm{kgCOD}$ by end of the experiment. It was observed that decrease of COD value below $50 \mathrm{mg} . \mathrm{L}^{-1}$ limits the generation of energy which reduces the NERs for low strength wastewater substantially. The less NERs during the initial phase for high-strength wastewater systems were due to more activation time required to produce electrons because of high $\mathrm{pH}$ and organic loading. Though during 144-288 hours, NERs values for these systems showed increasing trends and superseded the decreasing trend of systems with low strength, medium-strength wastewater systems achieved maximum NERs values during 144-216 hours and then declined.

\section{Coulombic Efficiency}

The T1 achieved the highest CE of $22.11 \%$, showing that exoelectrogens were able to use that percentage of electrons 
Table 2: Performance of single chamber MFCs considering domestic wastewater as substrate.

\begin{tabular}{|c|c|c|c|c|c|c|c|c|c|c|c|}
\hline S.No. & Type & $\begin{array}{l}\text { Substrate } \\
\text { concentra- } \\
\text { tion }\end{array}$ & $\begin{array}{l}\text { Type of } \\
\text { MFC }\end{array}$ & $\begin{array}{l}\text { Working } \\
\text { volume }\end{array}$ & Anode & Cathode & Voltage & $\begin{array}{l}\text { COD } \\
\text { removal } \\
(\%)\end{array}$ & $\begin{array}{l}\text { Max } \\
\text { Power } \\
\text { Density }\end{array}$ & $\begin{array}{l}\text { Cou- } \\
\text { lombic } \\
\text { Efficien- } \\
\text { cy }(\%)\end{array}$ & Reference \\
\hline 1 & Batch & $\begin{array}{l}155 \pm 36 \text { to } \\
232 \pm 84\end{array}$ & $\begin{array}{l}\text { SC-MFC; } \\
\text { No mem- } \\
\text { brane }\end{array}$ & $130 \mathrm{~mL}$ & $\begin{array}{l}\text { Graphite } \\
\text { brush } \\
\text { anodes }\end{array}$ & Carbon cloth & $\begin{array}{l}0.41 \pm \\
0.05 \mathrm{~V}\end{array}$ & $>90$ & $\begin{array}{l}120 \\
\mathrm{~mW} / \mathrm{m}^{2}\end{array}$ & - & $\begin{array}{l}\text { (Ahn et al. } \\
\text { 2014) }\end{array}$ \\
\hline \multirow[t]{2}{*}{2} & \multirow[t]{2}{*}{ Continuous } & 410 & $\begin{array}{l}\text { SC-MFC; } \\
\text { with } 2 \\
\text { cathodes }\end{array}$ & $\begin{array}{l}\text { Variable } \\
\text { flow rate } \\
(30-140 \\
\mathrm{mL} / \mathrm{h})\end{array}$ & $\begin{array}{l}\text { Graphite } \\
\text { fiber } \\
\text { brushes }\end{array}$ & $\begin{array}{l}\text { Activated } \\
\text { carbon with } \\
\text { polyvi- } \\
\text { nylidene }\end{array}$ & - & $64.8 \pm 1.7$ & $\begin{array}{l}\text { Power } \\
-1.30 \\
\text { to } 1.36 \\
\mathrm{~mW}\end{array}$ & $\begin{array}{l}18 \pm 5 \text { to } \\
29 \pm 3\end{array}$ & \multirow[t]{2}{*}{$\begin{array}{l}\text { (Kim et al. } \\
\text { 2015) }\end{array}$} \\
\hline & & 410 & $\begin{array}{l}\text { SC-MFC; } \\
\text { Single an- } \\
\text { ode single } \\
\text { cathode }\end{array}$ & $\begin{array}{l}\text { Variable } \\
\text { flow rate } \\
(20-100 \\
\mathrm{mL} / \mathrm{h})\end{array}$ & & $\begin{array}{l}\text { fluoride } \\
\text { (PVDF) } \\
\text { binder }\end{array}$ & - & $69.0 \pm 0.4$ & $\begin{array}{l}\text { Power } \\
-1.00 \\
\text { to } 1.22 \\
\mathrm{~mW}\end{array}$ & $\begin{array}{l}18 \pm 2 \text { to } \\
36 \pm 2\end{array}$ & \\
\hline \multirow[t]{2}{*}{3} & \multirow[t]{2}{*}{ Batch } & 303.69 & $\begin{array}{l}\text { SC-MFC } \\
\text { with sep- } \\
\text { arator }\end{array}$ & $130 \mathrm{~mL}$ & $\begin{array}{l}\text { Graphite } \\
\text { fiber } \\
\text { brush }\end{array}$ & Carbon cloth & $0.58 \mathrm{~V}$ & $\begin{array}{l}62.4 \text { to } \\
94.1\end{array}$ & $\begin{array}{l}328.11 \\
\mathrm{~mW} / \mathrm{m}^{2}\end{array}$ & $\begin{array}{l}9.2 \text { to } \\
31.4\end{array}$ & \multirow[t]{2}{*}{$\begin{array}{l}\text { (Ahn \& } \\
\text { Logan } \\
2013)\end{array}$} \\
\hline & & 303.69 & $\begin{array}{l}\text { SC-MFC } \\
\text { without } \\
\text { separator }\end{array}$ & & & & $0.54 \mathrm{~V}$ & $\begin{array}{l}81.5 \text { to } \\
93.3\end{array}$ & $\begin{array}{l}282.29 \\
\mathrm{~mW} / \mathrm{m}^{2}\end{array}$ & $\begin{array}{l}1.5 \text { to } \\
23.3\end{array}$ & \\
\hline \multirow[t]{3}{*}{4} & Batch & $545 \pm 5$ & $\begin{array}{l}\text { SC-MFC } \\
\text { without } \\
\text { cloth } \\
\text { separator }\end{array}$ & $140 \mathrm{~mL}$ & $\begin{array}{l}\text { Carbon } \\
\text { fiber } \\
\text { brush }\end{array}$ & $\begin{array}{l}\text { Carbon cloth } \\
\text { cathode with } \\
\text { a Pt catalyst } \\
\text { without a } \\
\text { separator } \\
\text { (Pt-NS) }\end{array}$ & - & $82 \pm 0$ & $\begin{array}{l}315 \pm 16 \\
\mathrm{~mW} / \mathrm{m}^{2}\end{array}$ & $26 \pm 1$ & \multirow[t]{3}{*}{$\begin{array}{l}\text { (Stager et } \\
\text { al. 2017) }\end{array}$} \\
\hline & Batch & $330 \pm 5$ & $\begin{array}{l}\text { SC-MFC } \\
\text { with cloth } \\
\text { separator }\end{array}$ & & & $\begin{array}{l}\text { Activated } \\
\text { carbon cath- } \\
\text { ode (AC-CS) }\end{array}$ & - & $59 \pm 3$ & $\begin{array}{l}161 \pm 14 \\
\mathrm{~mW} / \mathrm{m}^{2}\end{array}$ & $19 \pm 1$ & \\
\hline & Continuous & $1050 \pm 2$ & $\begin{array}{l}\text { SC-MFC } \\
\text { without } \\
\text { cloth } \\
\text { separator }\end{array}$ & & & $\begin{array}{l}\text { Activated } \\
\text { carbon } \\
\text { cathode } \\
\text { with a cloth } \\
\text { separator } \\
\text { (AC-CS) }\end{array}$ & - & $28 \pm 5$ & $\begin{array}{l}257 \\
\mathrm{~mW} / \mathrm{m}^{2}\end{array}$ & $7 \pm 2$ & \\
\hline 5 & Batch & $223 \pm 6$ & $\begin{array}{l}\text { SC-MFC; } \\
\text { No mem- } \\
\text { brane }\end{array}$ & $26 \mathrm{~mL}$ & $\begin{array}{l}\text { Graphite } \\
\text { fiber } \\
\text { brush }\end{array}$ & $\begin{array}{l}\text { Carbon cloth } \\
\text { with Pt. cata- } \\
\text { lyst layer }\end{array}$ & - & $\begin{array}{l}55 \text { (Ap- } \\
\text { prox.) }\end{array}$ & - & 21 & $\begin{array}{l}\text { (Zhang et } \\
\text { al. 2015) }\end{array}$ \\
\hline \multirow[t]{2}{*}{6} & \multirow[t]{2}{*}{ Batch } & $237.3 \pm 8.0$ & $\begin{array}{l}\text { SC-MFC; } \\
\text { Mn coating }\end{array}$ & $2000 \mathrm{~mL}$ & $\begin{array}{l}\text { Circular } \\
\text { graphite } \\
\text { plate }\end{array}$ & Carbon Cloth & $0.5 \mathrm{~V}$ & 45.55 & $\begin{array}{l}48.4 \pm \\
10.16 \\
\mathrm{~mW} / \mathrm{m}^{2}\end{array}$ & - & \multirow[t]{2}{*}{$\begin{array}{l}\text { (Tatinclaux } \\
\text { et al. } 2018\end{array}$} \\
\hline & & $293.3 \pm 81.5$ & $\begin{array}{l}\text { SC-MFC; } \\
\text { Pt coating }\end{array}$ & & & & $0.45 \mathrm{~V}$ & 27.98 & $\begin{array}{l}65.4 \pm \\
4.6 \mathrm{~mW} / \\
\mathrm{m}^{2}\end{array}$ & - & \\
\hline \multirow[t]{6}{*}{7} & \multirow[t]{6}{*}{ Batch } & 1920 & $\begin{array}{l}\text { SC-MFC; } \\
\text { No mem- } \\
\text { brane }\end{array}$ & $165 \mathrm{~mL}$ & $\begin{array}{l}\text { Graphite } \\
\text { rod }\end{array}$ & $\begin{array}{l}\text { Aluminium } \\
\text { sheet }\end{array}$ & $0.67 \mathrm{~V}$ & 83.33 & $\begin{array}{l}267.19 \\
\mathrm{~mW} / \mathrm{m}^{2}\end{array}$ & $\begin{array}{l}0.01 \text { to } \\
0.25\end{array}$ & \multirow[t]{6}{*}{ This study } \\
\hline & & 1920 & $\begin{array}{l}\text { SC-MFC; } \\
\text { No mem- } \\
\text { brane }\end{array}$ & & & & $0.71 \mathrm{~V}$ & 91.66 & $\begin{array}{l}304.46 \\
\mathrm{~mW} / \mathrm{m}^{2}\end{array}$ & $\begin{array}{l}0.04 \text { to } \\
4.55\end{array}$ & \\
\hline & & 288 & $\begin{array}{l}\text { SC-MFC; } \\
\text { No mem- } \\
\text { brane }\end{array}$ & & & & $0.61 \mathrm{~V}$ & 66.66 & $\begin{array}{l}224.21 \\
\mathrm{~mW} / \mathrm{m}^{2}\end{array}$ & $\begin{array}{l}2.58 \text { to } \\
9.33\end{array}$ & \\
\hline & & 360 & $\begin{array}{l}\text { SC-MFC; } \\
\text { No mem- } \\
\text { brane }\end{array}$ & & & & $0.66 \mathrm{~V}$ & 82.22 & $\begin{array}{l}259.24 \\
\mathrm{~mW} / \mathrm{m}^{2}\end{array}$ & $\begin{array}{l}1.27 \text { to } \\
9.86\end{array}$ & \\
\hline & & 96 & $\begin{array}{l}\text { SC-MFC; } \\
\text { No mem- } \\
\text { brane }\end{array}$ & & & & $0.36 \mathrm{~V}$ & 83.33 & $\begin{array}{l}78.27 \\
\mathrm{~mW} / \mathrm{m}^{2}\end{array}$ & $\begin{array}{l}4.80 \text { to } \\
22.11\end{array}$ & \\
\hline & & 128 & $\begin{array}{l}\text { SC-MFC; } \\
\text { No mem- } \\
\text { brane }\end{array}$ & & & & $0.41 \mathrm{~V}$ & 75 & $\begin{array}{l}98.27 \\
\mathrm{~mW} / \mathrm{m}^{2}\end{array}$ & $\begin{array}{l}4.05 \text { to } \\
9.97\end{array}$ & \\
\hline
\end{tabular}




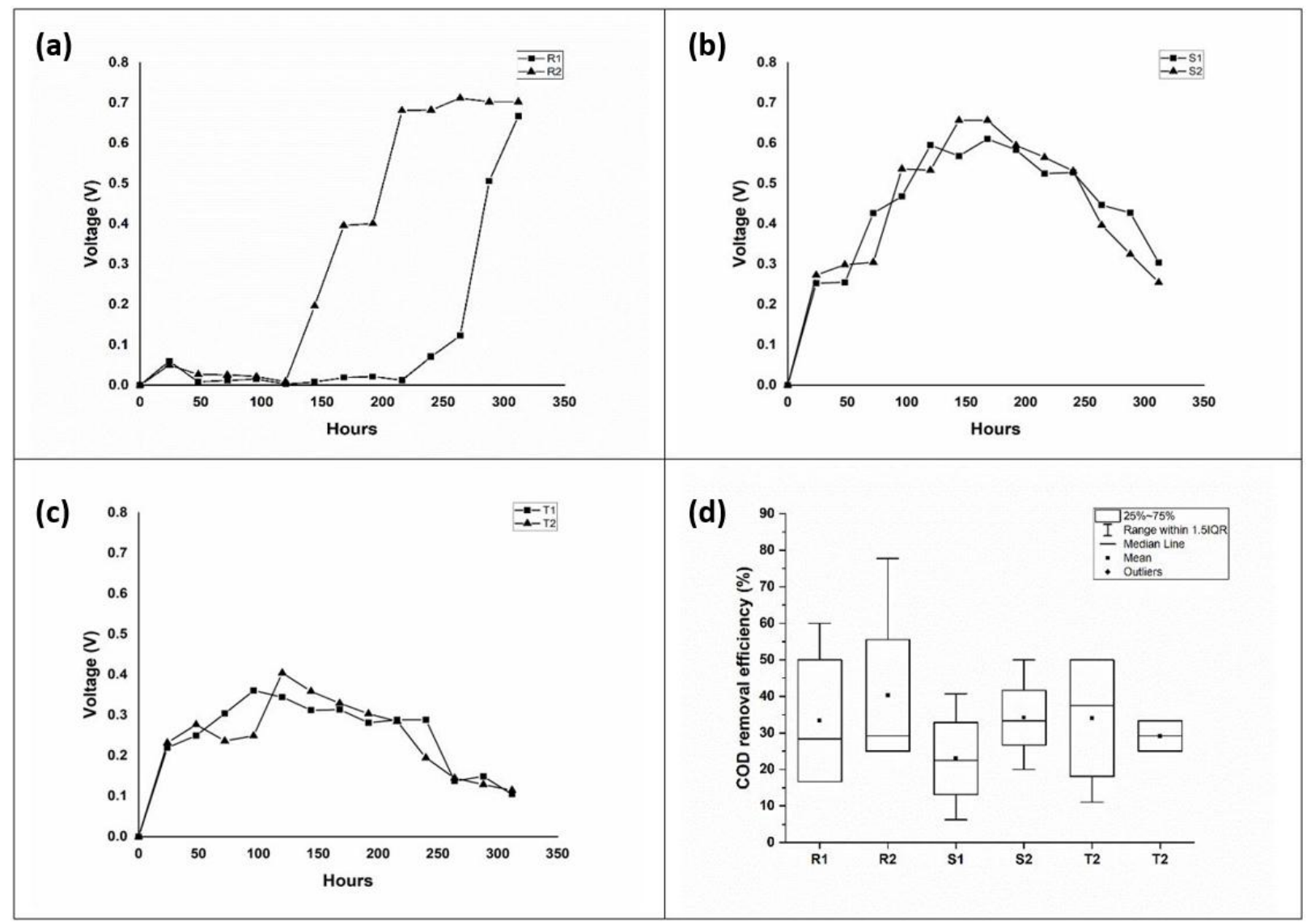

Fig. 3: Voltage generation with respect to time; (a) - High strength wastewater (R1, R2), (b) - Medium strength wastewater (S1, S2), (c) - Low strength wastewater $(\mathrm{T} 1, \mathrm{~T} 2),(\mathrm{d})$ - Box plot showing the variability of voltage generation in all systems.

generated from the substrate for energy generation. R1 and R2 utilized only a small fraction of electrons generated in form of current (Max CE in R1, R2 $=0.25 \%, 4.55 \%$ ), which indicates less electron settlement on the anode. This might be due to higher internal resistance due to the settleable non-conductive particles which are available in raw wastewater. As wastewater was collected from different treatment plants, the difference in CE of R1 and R2 might be due to the varying concentrations of other constituents like nitrates, phosphates, and chlorides. The possibilities of electron loss due to alternate electron acceptors like dissolved oxygen or short-circuiting also cannot be ruled out (Kim et al. 2015). Short-circuiting in systems can be avoided by coating the internal surface of the cathode zone with proton exchange membranes but the cost of fabrication will increase substantially. For further comparison of performance, the average $\mathrm{CE}$ of similar substrate concentrations was considered. Systems with high-strength wastewater produced an average CE of $2.40 \%$, medium-strength wastewater produced $9.59 \%$, and low-strength wastewater produced $13.80 \%$ which has been shown in Fig. 4. In the case of low strength wastewater systems, there is an increasing trend of CE till 144 and 216 hours respectively, after which it decreased from 13.80 to $5.66 \%$. This implies a depleted substrate in these systems, as they gradually decreased after reaching a maximum value. Initial CE was low in systems with high wastewater strength, but it steadily grew over time, indicating the development of electrogenic microbial growth over the course of 216-288 hours.

\section{CONCLUSION}

The overall performances were satisfactory, as COD reduction and energy generation were comparable with similar MFC designs. Systems with high organic loading removed more COD than other systems and produced more maximum voltages. However, in terms of electrochemical activities, they struggled to deliver initially and systems with lower organic loading performed better, thus providing more energy recovery and coulombic efficiency. Higher COD loading 


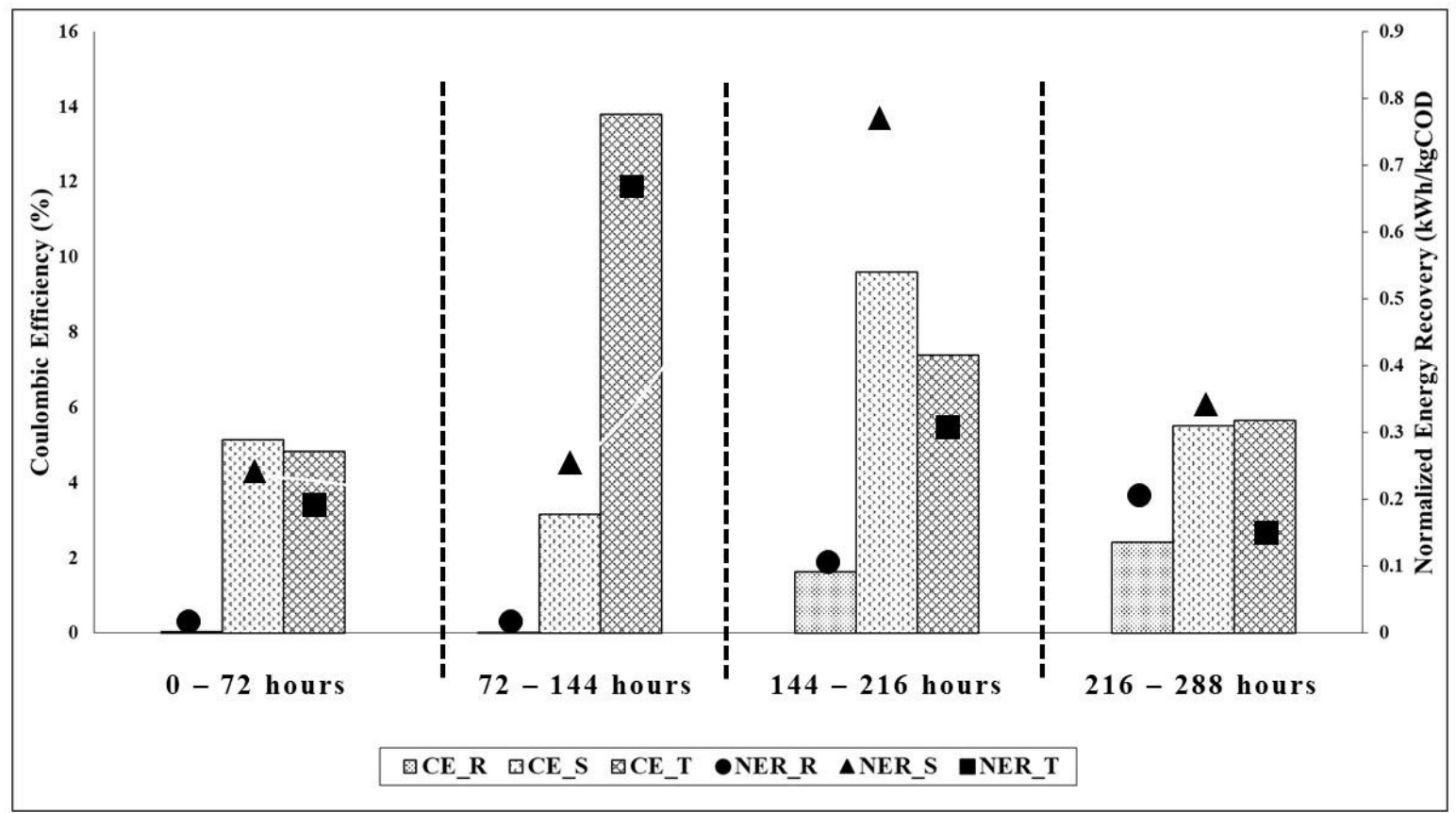

Fig. 4: The variation of Coulombic efficiency (CE) \& Normalized Energy recovery with time [represented as \{CE_R, NER_R (Average of R1, R2) \}, $\left\{C E \_S, N E R \_S\right.$ (Average of S1, S2) \} and CE_T, NER_T (average of T1, T2) \}].

required more time in starting electrochemical activities of MFCs and have more energy losses. On the other hand, lower organic loading can utilize produced electrons efficiently but might need new substrate feed after some operation time. They even have more stability and give equivalent performance as systems with high organic loading. The short circuit did not seem to affect the performance but still, a detailed study for obtaining the mechanism of electron transfer and relation of performance with other constituents like nitrates, sulfates, and chlorides are required. Also, after observing the overall performance of fabricated MFC's in comparison to other studies, the use of recyclable/reusable materials is recommended after proper pretreatment.

\section{ACKNOWLEDGEMENT}

The authors acknowledge the help of VIT, Vellore, India for the financial \& technical support provided under Seed Fund for Research (RGEMS) to carry out this research work.

\section{ABBREVIATIONS}

$\begin{array}{ll}\text { MFC } & \text { Microbial Fuel Cell } \\ \text { R1, R2 } & \text { Experimental systems with high strength wastewater } \\ \text { S1, S2 } & \text { Experimental systems with medium strength wastewater } \\ \text { T1, T2 } & \text { Experimental systems with low strength wastewater } \\ \text { COD } & \text { Chemical Oxygen Demand }\end{array}$

$\begin{array}{ll}\text { NER } & \text { Normalized Energy Recovery } \\ \text { PD } & \text { Power density } \\ \text { CE } & \text { Coulombic Efficiency }\end{array}$

\section{REFERENCES}

Abdelkader, A., Osman, A.I., Halawy, S.A. and Mohamed, M.A. 2018. Preparation and characterization of mesoporous - $\mathrm{A} 12 \mathrm{O} 3$ recovered from aluminum cans waste and its use in the dehydration of methanol to dimethyl ether. J. Mater. Cycles Waste Manag., 20: 1428-1436. https:// doi.org/10.1007/s10163-018-0702-0

Abdelrahman, E.A. 2018. Synthesis of zeolite nanostructures from waste aluminum cans for efficient removal of malachite green dye from aqueous media. J. Mol. Liq., 253: 72-82. https://doi.org/10.1016/j. molliq.2018.01.038

Abdelrahman, E.A. and Hegazey, R.M. 2019. Utilization of waste aluminum cans in the fabrication of hydroxysodalite nanoparticles and their chitosan biopolymer composites for the removal of $\mathrm{Ni}(\mathrm{II})$ and $\mathrm{Pb}$ (II) ions from aqueous solutions: Kinetic, equilibrium, and reusability studies. Microchem. J., 145: 18-25. https://doi.org/10.1016/j.microc.2018.10.016

Ahn, Y., Hatzell, M.C., Zhang, F. and Logan, B.E. 2014. Different electrode configurations to optimize the performance of multi-electrode microbial fuel cells for generating power or treating domestic wastewater. J. Power Sources, 249: 440-445. https://doi.org/10.1016/j.jpowsour.2013.10.081

Ahn, Y. and Logan, B.E. 2013. Domestic wastewater treatment using multi-electrode continuous flow MFCs with a separator electrode assembly design. Appl. Microbiol. Biotechnol., 97: 409-416. https://doi. org/10.1007/s00253-012-4455-8

APHA. 2017. Standard methods for the examination of water and wastewater. 23rd edition. American Public Health Association, Washington DC, USA. 
César, A.C.G., Carvalho, J.A. and Nascimento L.F.C. 2015. Association between NOx exposure and deaths caused by respiratory diseases in a medium-sized Brazilian city. Brazilian J. Med. Biol. Res., 48: 1130-1135. https://doi.org/10.1590/1414-431X20154396

Chen, S. and Smith, A.L. 2018. Methane-driven microbial fuel cells recover energy and mitigate dissolved methane emissions from anaerobic effluents. Environ. Sci. Water Res. Technol., 4: 67-79. https://doi.org/10.1039/ c7ew00293a

Chen, Y.M., Wang, C.T., Yang, Y.C. and Chen, W.J. 2013. Application of aluminum-alloy mesh composite carbon cloth for the design of anode/cathode electrodes in Escherichia coli microbial fuel cell. Int. J. Hydrogen Energy., 38: 11131-11137. https://doi.org/10.1016/j.ijhydene.2013.01.010

Choudhury, P., Uday, U.S.P., Mahata, N., Nath Tiwari, O., Narayan Ray, R., Kanti Bandyopadhyay, T. and Bhunia, B. 2017. Performance improvement of microbial fuel cells for wastewater treatment along with value addition: A review on past achievements and recent perspectives. Renew. Sustain. Energy Rev., 79: 372-389. https://doi.org/10.1016/j. rser.2017.05.098

Das, B., Thakur, S., Chaithanya, M.S. and Biswas, P. 2019. Batch investigation of constructed wetland microbial fuel cell with reverse osmosis (RO) concentrates and wastewater mix as substrate. Biomass and Bioenergy., 122: 231-237. https://doi.org/10.1016/j.biombioe.2019.01.017

Ezziat, L., Elabed, A., Ibnsouda, S. and El Abed, S. 2019. Challenges of microbial fuel cell architecture on heavy metal recovery and removal from wastewater. Front. Energy Res., 7: 1-13. https://doi.org/10.3389/ fenrg.2019.00001

Feng, Y., He, W., Liu, J., Wang, X., Qu, Y. and Ren, N. 2014. A horizontal plug flow and stackable pilot microbial fuel cell for municipal wastewater treatment. Bioresour. Technol., 156: 132-138. https://doi.org/10.1016/j. biortech.2013.12.104

Ge, Z. and He, Z. 2016. Long-term performance of a 200 liter modularized microbial fuel cell system treating municipal wastewater: Treatment, energy, and cost. Environ. Sci. Water Res. Technol., 2: 274-281. https:// doi.org/10.1039/c6ew00020g

Gielen, D., Boshell, F., Saygin, D., Bazilian, M.D., Wagner, N. and Gorini, R. 2019. The role of renewable energy in the global energy transformation. Energy Strateg. Rev., 24: 38-50. https://doi.org/10.1016/j.esr.2019.01.006

He, L., Du, P., Chen, Y., Lu, H., Cheng, X., Chang, B. and Wang, Z. 2017. Advances in microbial fuel cells for wastewater treatment. Renew. Sustain. Energy Rev., 71: 388-403. https://doi.org/10.1016/j.rser.2016.12.069

Kannan, M.V. and Kumar, G.G. 2016. Current status, key challenges, and its solutions in the design and development of graphene-based ORR catalysts for microbial fuel cell applications. Biosens. Bioelectron., 77: 1208-1220. https://doi.org/10.1016/j.bios.2015.10.018

Kim, K.Y., Yang, W. and Logan, B.E. 2015. Impact of electrode configurations on retention time and domestic wastewater treatment efficiency using microbial fuel cells. Water Res., 80: 41-46.

Lefebvre, O., Shen, Y. and Ng, H.Y. 2012. Optimization of a microbial fuel cell for wastewater treatment using recycled scrap metals as a cost-effective cathode material. Bioresour. Technol., 127C: 158-164. https:// doi.org/10.1016/j.watres.2015.05.021

Li, J., Luo, G., He, L.J., Xu, J. and Lyu, J. 2018. Analytical approaches for determining chemical oxygen demand in water bodies: A review. Crit. Rev. Anal. Chem., 48: 47-65. https://doi.org/10.1080/10408347.2017.1370670

Logan, B.E., Hamelers, B., Rozendal, R., Schröder, U., Keller, J., Freguia, S., Aelterman, P., Verstraete, W. and Rabaey, K. 2006. Microbial fuel cells: Methodology and technology. Environ. Sci. Technol., 40: 5181-5192. https://doi.org/10.1021/es0605016

Luo, S. and He, Z. 2016. Ni-coated carbon fiber as an alternative cathode electrode material to improve the cost efficiency of microbial fuel cells. Electrochim. Acta., 222: 338-346. https://doi.org/10.1016/j.electacta.2016.10.178

Maktabifard, M., Zaborowska, E. and Makinia, J. 2018. Achieving energy neutrality in wastewater treatment plants through energy savings and enhancing renewable energy production. Rev. Environ. Sci. Biotechnol., 17: 655-689. https://doi.org/10.1007/s11157-018-9478-x

Mansoorian, H.J., Mahvi, A.H., Jafari, A.J. and Khanjani, N. 2016. Evaluation of dairy industry wastewater treatment and simultaneous bioelectricity generation in a catalyst-less and mediator-less membrane microbial fuel cell. J. Saudi Chem. Soc., 20: 88-100. https://doi.org/10.1016/j. jscs.2014.08.002

Martínez, S.S., Albañil Sánchez, L., Álvarez Gallegos, A.A. and Sebastian, P.J. 2007. Coupling a PEM fuel cell and the hydrogen generation from aluminum waste cans. Int. J. Hydrogen Energy., 32: 3159-3162. https:// doi.org/10.1016/j.ijhydene.2006.03.015

Matweb. 2020. Characteristics of Aluminum 3004-H19. http://www.matweb.com/search/datasheet_print.aspx?matguid=ec6a8753c110472ebcead3a2f95457ba\&n=1

Narayanan, A. and Thakur, M. 2010. Quadratic electro-optic effect in the nonconjugated conductive polymer iodine-doped poly( $\beta$-pinene $)$ measured at longer wavelengths including $1.55 \mu \mathrm{m}$. Solid State Commun., 150: 375-378. https://doi.org/10.1016/j.ssc.2009.11.036

Palanisamy, D., Chockalingam, L.R. and Murugan, D. 2020. Microbial fuel cell for effluent treatment and sustainable power generation. Energy Sources, Part A Recover. Util. Environ. Eff., 1: 1-13. https://doi.org/10. 1080/15567036.2020.1796844

Seeber, R., Zanardi, C. and Inzelt, G. 2015. Links between electrochemical thermodynamics and kinetics. ChemTexts., 1: 18. https://doi.org/10.1007/ s40828-015-0018-9

Stager, J.L., Zhang, X. and Logan, B.E. 2017. The addition of acetate improves the stability of power generation using microbial fuel cells treating domestic wastewater. Bioelectrochemistry, 118: 154-160.

https://doi.org/10.1016/j.bioelechem.2017.08.002

Tatinclaux, M., Gregoire, K., Leininger, A., Biffinger, J.C., Tender, L., Ramirez, M., Torrents, A. and Kjellerup, B. V. 2018. Electricity generation from wastewater using a floating air cathode microbial fuel cell. Water-Energy Nexus., 1: 97-103. https://doi.org/10.1016/j.wen.2018.09.001

Thakur, S. and Das, B. 2020. Performance evaluation of microbial fuel cell with sewage wastewater and RO concentrate using composite anode made of Luffa aegyptiaca. Environ. Prog. Sustain. Energy., 76: e13504. https://doi.org/10.1002/ep.13504

US EPA. 2015. Advancing Sustainable Materials Management: Facts and Figures 2013, United States Environmental Protection Agency.

Velvizhi, G. and Venkata Mohan, S. 2011. Biocatalyst behavior under self-induced electrogenic microenvironment in comparison with anaerobic treatment: Evaluation with pharmaceutical wastewater for multi-pollutant removal. Bioresour. Technol., 102: 10784-10793. https://doi. org/10.1016/j.biortech.2011.08.061

Wu, Q., Jiao, S., Ma, M. and Peng, S. 2020. Microbial fuel cell system: A promising technology for pollutant removal and environmental remediation. Environ. Sci. Pollut. Res., 27: 6749-6764. https://doi.org/10.1007/ s11356-020-07745-0

Yaseen, D.A. and Scholz, M. 2019. Impact of pH on the treatment of artificial textile wastewater containing azo dyes using pond systems. Int. J. Environ. Res., 13: 367-385. https://doi.org/10.1007/s41742-019-00180-1

Yoo, S.J., Yoon, H.S., Jang, H.D., Hong, S.T., Park, H.S., Park, S.U., Kwak, D.H. and Lee, S.I. 2007. Synthesis of aluminum ethoxide from used aluminum cans. Korean J. Chem. Eng., 24: 872-876. https://doi.org/10.1007/ s11814-007-0057-z

Zhang, X., He, W., Ren, L., Stager, J., Evans, P.J. and Logan, B.E. 2015. COD removal characteristics in air-cathode microbial fuel cells. Bioresour. Technol., 176: 23-31. https://doi.org/10.1016/j.biortech.2014.11.001

Zou, C., Zhao, Q., Zhang, G. and Xiong, B. 2016. Energy revolution: From a fossil energy era to a new energy era. Nat. Gas Ind. B. 3: 1-11. https:// doi.org/10.1016/j.ngib.2016.02.001

Zuo, Y., Cheng, S., Call, D.F. and Logan, B. 2007. Scalable tubular membrane cathodes for microbial fuel cell applications. ACS Natl. Meet. B. Abstr., 41: 3347-3353. 